Theory Matters 

Martin Middeke $•$ Christoph Reinfandt Editors

\section{Theory Matters}

\section{The Place of Theory in Literary and Cultural Studies Today}




\section{Editors}

Martin Middeke

Chair of English Literature

University of Augsburg

Augsburg, Germany

\author{
Christoph Reinfandt \\ Chair of English Literature \\ University of Tübingen \\ Tübingen, Germany
}

ISBN 978-1-137-47427-8

ISBN 978-1-137-47428-5 (eBook)

DOI $10.1057 / 978-1-137-47428-5$

Library of Congress Control Number: 2016942080

(C) The Editor(s) (if applicable) and The Author(s) 2016

The author(s) has/have asserted their right(s) to be identified as the author(s) of this work in accordance with the Copyright, Designs and Patents Act 1988.

This work is subject to copyright. All rights are solely and exclusively licensed by the Publisher, whether the whole or part of the material is concerned, specifically the rights of translation, reprinting, reuse of illustrations, recitation, broadcasting, reproduction on microfilms or in any other physical way, and transmission or information storage and retrieval, electronic adaptation, computer software, or by similar or dissimilar methodology now known or hereafter developed.

The use of general descriptive names, registered names, trademarks, service marks, etc. in this publication does not imply, even in the absence of a specific statement, that such names are exempt from the relevant protective laws and regulations and therefore free for general use. The publisher, the authors and the editors are safe to assume that the advice and information in this book are believed to be true and accurate at the date of publication. Neither the publisher nor the authors or the editors give a warranty, express or implied, with respect to the material contained herein or for any errors or omissions that may have been made.

Printed on acid-free paper

This Palgrave Macmillan imprint is published by Springer Nature The registered company is Macmillan Publishers Ltd. London 


\section{ACKNOWLEDGEMENTS}

A collaborative effort such as this is motivated by and needs to give recognition to various sources of encouragement and inspiration. Foremost, our thanks go to all the participants in this project and their dedication and fruitful cooperation throughout, and we also happily extend these thanks to the friendly staff and our generous and patient editors at Palgrave, Tomas René and Ben Doyle. We would like to acknowledge the insights we gained from many discussions with colleagues and students in Augsburg, Tübingen, Freiburg, and Johannesburg during conference panels, seminars, and master classes on literary and cultural theory. Finally, our warm thanks go to both teams of research staff at our home universities-Despina Repa, Julia Rössler, Elisabeth Schmitt, Christina Schönberger, Ricarda Sorg, Korbinian Stöckl, and, especially, Martin Riedelsheimer on the Augsburg side; Eva Maria Rettner, Bianca Klose, Nina Plachta, and Philipp Multhaupt on the Tübingen side-for their reliability, diligence, creativity, and their perfectly cheerful mood without which the editorial preparation of this volume would have been impossible. As always, any errors and shortcomings, of course, remain all ours.

On a final note, we should like to express our sadness about and sympathy over the sudden death of one of our contributors. Herbert Grabes, Professor of English and American Literature at the University of Giessen, Germany, died on 5 December 2015, aged 79. Professor Grabes was a literary scholar and a philosopher who for many years played an important role in the advancement of literary and cultural theory in Germany and abroad. We shall miss him.

Martin Middeke and Christoph Reinfandt Augsburg and Tübingen, December 2015 



\section{CONTEnTs}

1 Introduction: The Place of Theory Today 1 Martin Middeke and Christoph Reinfandt

Part I Metatheory

2 Comes the Revolution 17 J. Hillis Miller

3 Literary Theory in Reverse: The Literariness of Theory Gerold Sedlmayr

4 Misreading Shelley, Misreading Theory: Deconstruction, Media, and Materiality

Christian Huck

5 'I am, yet what I am': Theory, Being, and Dis-appearance 65 Julian Wolfreys

6 Matter Against Materialism: Bruno Latour and the Turn to Objects Benjamin Noys 
7 Avoiding Poststructuralism at Its Root: Towards a New Literary Theory

Dino Galetti

8 Interlude I: The Cultures of Reflexivity

Martin Middeke and Christoph Reinfandt

Part II Cultural Theory

9 The University: A Matter of Theoretical Importance Thomas Docherty

10 When Theory Is Not Enough: A Material Turn in Gender Studies

Ingrid Hotz-Davies

11 Luhmann in da Contact Zone: Towards a Postcolonial Critique of Sociological Systems Theory Lars Eckstein and Christoph Reinfandt

12 Passive Voice: Democratic Indifference and the Vibrant Matter of Literature

Dirk Wiemann

13 Managing Complexity: The 'Literary Turn' in Organization Studies

Nicola Glaubitz

14 Interlude II: Ideologies of Habitus

Martin Middeke and Christoph Reinfandt

Part III Critical Theory

15 Ecological Transformations of Critical Theory Hubert Zapf 
16 The Literary Work as Ethical Event

Derek Attridge

17 Ethics and Agency: The Limits and Necessity of Ethical Criticism

Sebastian Domsch

18 The Art of Compearance: Ethics, (Reading) Literature, and the Coming Community

Martin Middeke

19 Narrative Theory at the Limit

Richard Walsh

20 Interlude III: On Interpretation

Martin Middeke and Christoph Reinfandt

Part IV Textual Theory

21 The Fate of Texts Under Changing Theory Herbert Grabes

22 Latour and Literature

David J. Alworth

23 Reading Textures

Christoph Reinfandt

24 Plato or Aristotle? Form and Textuality

Sukanta Chaudhuri

Martin Middeke and Christoph Reinfandt 



\section{Contributors}

David Alworth is Assistant Professor of English and of History and Literature at Harvard University, USA.

Derek Attridge is Professor of English at the University of York, UK.

Sukanta Chaudhuri is Professor Emeritus at Jadavpur University, Kolkata, India.

Thomas Docherty is Professor of English and Comparative Literary Studies at the University of Warwick, UK.

Sebastian Domsch is Professor of Anglophone Literature \& Culture at the University of Greifswald, Germany.

Lars Eckstein is Professor of Anglophone Literatures and Cultures at the University of Potsdam, Germany.

Dino Galetti is Lecturer in the Department of English, University of Johannesburg, South Africa and Visiting Scholar at the State University of New York (Stony Brook), USA.

Nicola Glaubitz is Lecturer in English Literature and Digital Philology at the Technical University of Darmstadt, Germany.

Herbert Grabes (1936-2015) was Professor of English and American Literature at the University of Gießen, Germany.

Ingrid Hotz-Davies is Professor of English Literature and Gender Studies at the University of Tübingen, Germany. 
Christian Huck is Professor of Cultural and Media Studies at the University of Kiel, Germany.

Martin Middeke is Professor of English Literature at the University of Augsburg, Germany, and Visiting Professor of English at the University of Johannesburg, South Africa.

J. Hillis Miller is Distinguished Research Professor Emeritus of English and Comparative Literature at the University of California, Irvine, USA.

Benjamin Noys is Professor of Critical Theory at the University of Chichester, UK.

Christoph Reinfandt is Professor of English Literature at the University of Tübingen, Germany.

Gerold Sedlmayr is Professor of British Cultural Studies at the Technical University of Dortmund, Germany.

Richard Walsh is Reader in English and Related Literature at the University of York, UK.

Dirk Wiemann is Professor of English Literature at the University of Potsdam, Germany.

Julian Wolfreys is Professor of English and Director of the Centre for Studies in Literature at the University of Portsmouth, UK.

Hubert Zapf is Professor of American Studies at the University of Augsburg, Germany. 